\title{
Ethno-Language Issue as a Source of Separatism and Instability in
}

\section{Ukraine}

\author{
Nikolay P. Medvedev ${ }^{1}$, Dmitriy E. Slizovskiy ${ }^{1}$, Viktor A. Glebov ${ }^{1}$, Vadim N. Medvedev ${ }^{2} \&$ Abdul Rahman \\ Amini $^{1}$ \\ ${ }^{1}$ Peoples' Friendship University of Russia (RUDN-University), Moscow, Russia \\ ${ }^{2}$ Russian Presidential Academy of National Economy and Public Administration (Ranepa), Russia \\ Correspondence: Nikolay P. Medvedev, RUDN-University, Moscow, Russia. E-mail: medvedev_rudn@mail.ru
}

Received: June 9, 2019 Accepted: August 25, $2019 \quad$ Online Published: August 31, 2019

doi:10.5539/jpl.v12n5p111 URL: https://doi.org/10.5539/jpl.v12n5p111

\begin{abstract}
The article analyzes the impact of ethno-linguistic policy on the separatism and political instability in Ukraine. The article examines the current provisions of the legislation of Ukraine on the development of language policy, as well as the provisions of the latest Law on the status of the state language in Ukraine.Ukraine has severalspecific features from the linguistic point of view, they are: bilingualism, uneven distribution of Russian and Ukrainian languages on the territory of the country and in different sectors of the social sphere, as well as ethno-linguistic, social and socio-cultural polarization of the Western, Central and South-Eastern parts of the country.

The Ukrainian language was recognized as the state languagein Ukraine in 1989. This preceded the signing of the Declaration on the State Independence of Ukraine in 1991. From that moment on, the Ukrainian language is considered a symbol of the new Ukraine. Raising the status of the Ukrainian language has become one of the central issues in the process of building an independent state.
\end{abstract}

The UN Security Council discussion in July 2019 on the language policy in Ukraine showed the world community's concern over the problem of ensuring the rights and freedoms of citizens and national minorities in Ukraine in connection with the adoption of the Law on the legal status of the state Ukrainian language and its use in education and public life.

The analysis focuses on the trends in the development of language policy, which is the source of aggravation of social processes in the form of separatism and destabilization of modern Ukraine and attempts of its modern political regime to finally complete the reorientation from Russia to the West at the legislative language level

Keywords: ethno-linguistic issue, political instability, ethno-political destabilization, language policy, separatism, conflicts, interethnic relations, national minorities, Ukrainization

\section{Relevance of the Topic}

The Law "On Ensuring the Functioning of the Ukrainian Language as the State Language" came into force in Ukraine on July 16 this year. Verkhovna Rada adopted this document in the second reading a few days after the victory of Vladimir Zelensky in the second round of the presidential elections on April 25. The Law guarantees the use of the Ukrainian language in the public space and does not apply to the sphere of private communication and religious ceremonies. According to the law, the Ukrainian language will necessarily be used in the state and municipal sectors, in the medical and transport sectors, in the labeling of goods and services, in the field of arts and education and in the media. Will this Law, its application and reality become a source of separatism and political instability in Ukraine? The question is not rhetorical, if we link this Law not only with the historical, socio-political and the language situation in Ukraine, but also with the discourse around the Law and Ukrainian language policy in the international context. (Ketsyan, 2011; Medvedev, 2018; PYZH, 2018; Ahmadi, et al 2014)

The conservative criticism of the modern political regime of Ukraine and its language policy in one way or another generate a discussion, the nature and content of which, on the one hand, inspires those who would like in the ongoing language policy to gain strength in the fact that the Ukrainian language will finally become a powerful national tool that will transform the human flow into a nation through the storage and transfer of culture, traditions and social consciousness of the people. On the other hand, it is supposed to end the yoke 
planted in the past through the Russification and "imperial" culture. The Ukrainian languageis hoped to become a linguistic and cultural basis for the solution of a difficult task:how to combine the ideas and values of the European culture with the need for a free development of the national Ukrainian culture. Equally real are the manifestations of separatism and political instability in the country, based on the ideas and realities of the modern linguistic and socio-political situation in Ukraine, on the current language policy and the adopted Law. ( Platonov,2015; Slisovskiy,2018; Savitskiy, 2019)

Specificity and originality of conditions for separatism and political instability in Ukraine.No matter how attractive the language policy in Ukraine is and no matter how powerful the Law "On Ensuring the Functioning of the Ukrainian Language as the State Language" is, the claims of its initiators and authors can be debunked and devalued, even exposed by the reality itself. This can be explained by a number of circumstances and conditions in which Ukraine has been immersed and remains. From the linguistic point of view, Ukraine has several specific features: real bilingualism, uneven distribution of Russian and Ukrainian languages on the territory of the country and in different sectors of the social sphere, as well as ethno-linguistic, social and socio-cultural polarization of the Western, Central and South-Eastern parts of the country. The Ukrainian language was recognized as the state language in Ukraine in 1989. This preceded the signing of the Declaration on the State Independence of Ukraine in 1991. From that moment on, the Ukrainian language is considered a symbol of the new Ukraine. Raising the status of the Ukrainian language has become one of the central issues in the process of building an independent state. Intheopinionofmanyresearchers , the provision of Article 10 of the Constitution of Ukraine that the state (Ukrainian) language is equal with the languages of national minorities does not solve a number of objectively existing problems and contradictions, it only confuses the political and legal aspect of the language problem.

In the world arena, the United Nations Security Council discussion in July 2019 on the language policy in Ukraine showed that the world community is concernedwith the problem of ensuring the rights and freedoms of citizens and national minorities in Ukraine in connectionwith the adoption of the Law on the legal status of the state Ukrainian language and its use in the spheres of education, public health and other spheres of public life.

With the adoption of the above Law, the priority task of the internal policy of Ukraine on the comprehensive development of the language of the titular nation and its status and the reduction of the use of the Russian language has ceased to be a task. It was solved at the legislative level. From that position, it makes no sense to say that the social status of the Ukrainian and Russian languages began to undergo significant changes. Just as it makes no sense to fix an earlier existing situation by saying that there was a sharp and not always balanced policy in Ukraine directed at the creation of a monolingual state without the consideration forthe real bilingualism in the country, the policythat met an ambiguous reaction in the society. There are legislative and state guarantees of elimination of differencesinthe position of structures of the Ukrainian language in respect to the structures of the power and society.Theoretically, we are dealing with a non-alternative relationship between the government and the Ukrainian language: the language and the governmentgo hand in hand. The Ukrainian language has lost its function of opposition to the authorities. Once again, theoretically, the structure of relations between the language and power, between languages, as a phenomenon of "separation of languages" and "rustle of languages," described in the philosophy by R. Barthes, is leveled and simplified.As for possible comments to the statistics, but not of purely statistical properties, the statistics simply indicates the correctness of the theoretical assumptions of the phenomenon of "separation of languages" throughout Ukraine. So, if the predominantly Ukrainian-speaking "West" of Ukraine has always fully supported Ukrainization, the predominantly Russian-speaking "East" met this idea very negatively. This can be largely explained by the fact that $29.6 \%$ of the population of Ukraine recognize Russian as their native language and are not interested in learning Ukrainian.Ukraine is home to 11.6 million Russians, who constitute $22 \%$ of its population. In some regions Russians make up more than $50 \%$ of the population. Thus, Russians constitute $67 \%$ of the population of Crimea, more than $55 \%$ of the population in Donetsk and Luhansk regions, more than $45 \%$ in Kharkiv and Dnepropetrovsk; 600 thousand Russians live in Kiev. According to the all-Ukrainian census, the population of Ukraine was 48 million 457 thousand people (51.7 million - according to the 1989 census), i.e. 403 thousand people less than according to the previous data. As for the national composition of the population of Ukraine, in most of its regions, according to the census, the Ukrainians prevail (37.54 million or $77.8 \%$ of the total population) and the remaining $22.2 \%$ of the population belong to the national minorities, among whomthere are 8334.1 thousand Russians.

Thus, it turned out that against the background of a catastrophic decline in the population of Ukraine (3.2 million people since 1989), the number of Ukrainians still increased by $0.3 \%$. The share of Ukrainians in the country as a whole increased by $5.1 \%$ ( $72.7 \%$ of the total population in $1989,77.8 \%$ - in 2001$)$. The situation with the 
Russians is opposite: their number has decreased dramatically - by 26.6 percent in 12 years. Their share in the total population of Ukraine was $17.3 \%$ in 2001 , compared with $23.1 \%$ in 1989 . The previous census of the population of Ukraine was held under the USSR, in the framework of the all-Union census, when it was not shameful to be called Russian, and maybe even more profitable than Ukrainian.The latest censuswas held in the independent state, where it is more profitable and honorable to be Ukrainian. If we add to this number the number of children born in mixed marriages, who identified themselves as ethnic Ukrainians due to the increased national consciousness and it turns out that the Russians did not disappear from Ukraine, but simply became Ukrainians. Even if we insist on the uniqueness of the situation in Ukraine, whose citizens are universally became representatives of the titular nation, the question arises: whether they wanted it and whether all of them were honest when changing their identity.

$67.5 \%$ of the population of Ukraine called Ukrainian theirmother language, $29.6 \%$ said that their native language was Russian, which is less by $3.2 \%$ compared to 1989, at the same time, the residents of Ukraine still continue to communicate with each other in Russian. Statistical errors and discrepancies still do not negate the fact that the language issue in Ukraine was clearly politicized.

Thus, it can be seen from the above data that with the adoption of the Law, the existing contradictions and disagreements in the society regarding the linguistic appearance of the country have sufficient grounds to move into the category of direct threats to the socio-political stability of the country and provoke a new wave of separatism.

\section{Discussion}

The question of ensuring the functioning of the Ukrainian language as the state language in Ukraine, strange as it may seem to someone is narrowed to the problems of attitude to the Russian language. This also has its own logic, since the independence of Ukraine, the topic of Ukrainian and Russian languages attracted the attention of the general public. Linguistic question is addressed not only by scientists, ethno-sociologists and socio-linguists, journalists, writers, but also by politicians and legislators.

It should be especially noted that the so-called state language expansion carried out in Ukraine, the desire to extend their language by declaring it a state (national) language to a foreign language community, is usually justified by the fact that indigenous people should be able to exercise their right to use the state language and foreign-speaking residents of a particular area should take on the responsibility to know the state language if it is included in the list of their official duties. Of course, in this case the language competence of the individual comes borders the ban on the profession, because it is assumed that the individual cannot take a number of official positions without a good knowledge of the state language. This generates social tension among the foreign-speaking (primarily Russian-speaking) population. On the discussion platform,we see readiness to demonstratethat the position of the Russian language in Ukraine is not infringed, while other debatersare constantly ready to give examples of just the opposite.

If we summarize the main trends related to the language reform not only in Ukraine, but also in most other former USSR republics, we can say that it is a revival of interest in national languages and national cultures, the desire to expand the social functions of national languages in different spheres of communication. It is the revival of traditional cultural and linguistic traditions, in some cases connected with the religious moments.

It may seem paradoxical, but in most of the new states of the post-Soviet space language policy recognize contrary to world practice the supremacy of language rights of the people, of the nation over the language rights of the individual.The role of the national language in the society is exaggerated,we see the desire to attribute to the language unusual functions, such as the mandatory function of the language of international communication in the country. This can be attributed to the desire to regulate the sphere of spontaneous communications, for example, interpersonal national communications and the sphere of family communications.

It is well known that for the successful functioning of a language as a state language, it is necessary that it is used by whole social strata (civil servants, service workers, people employed in education, culture, etc.). Thus, in the multinational regions of Ukraine, the language problem in the design of the attributes of statehood becomes universal, because it is relevant for both: a part of the national population, poorly fluent in the native Ukrainian language, and for the foreign-speaking population.

In the multinational regions of Ukraine, the desire to create a social need for the use of a particular language (primarily Ukrainian) by giving it the legal status of a state language is fraught with ethno-political conflicts.

Ethno-political conflictologists have long proved that the probability of national-language conflicts especially increases in developing countries, where there are processes of national self-determination and serious social 
changes, and in cases where the implementation of the laws on languages is formed under the conditions of functionally underdeveloped language, which is not even a significant part of its speakers, and when this language is imposed on representatives of another people.

That is why it is essential in the state national policy in the language field to determine its main parameters primarily taking into account the norms of international law and international practice, it is important to ensure a differentiated approach to the language situation in all multilingual regions of Ukraine.

At the same time, the Ukrainianstate authorities instead of stabilizing the situation in this area make such radical decisions of a nationalist nature, which further split the society on the ethnic and linguistic grounds. In 2017, three bills regulating the use of the Ukrainian language as the state language in the country were registered in the Parliament of Ukraine. In particular, one draft law "On the State Language" was registered according to which the Ukrainian language was to be used throughout the country in most areas of public life without taking into account the rights of national minorities to use their native languages.

It was thisdraft that was adopted by the Parliament and signed by President Poroshenko on the eve of the new presidential elections in Ukraine in 2019.

Some parliamentarians, authors of these bills, proposed to make the use of the Ukrainian language mandatory not only in all spheres of state and public life, but also in all media. It is proposed to oblige every citizen of Ukraine to know and speak Ukrainian. However, not everyone living on the territory of Ukraine will be obliged to speak the state language fluentlyit concerns only civil servants, diplomats, judges, lawyers, notaries, teachers and health workers and officers serving under the contract, as well as other employees of state and municipal institutions.

In addition, the Law envisages that foreign citizens wishing to obtain Ukrainian citizenship will have to pass exams on the knowledge of the Ukrainian language. The necessary level of proficiency will be determined by the national Commission on the standards of the Ukrainian language, which has yet to be set up. The Commission will also determine the necessary level of proficiency in the state language for certain positions and posts. For example, a candidate for the post of President of Ukraine will be required to have a certificate of knowledge of the Ukrainian language.In addition, the document proposes to introduce mandatory use of the state Ukrainian language during the elections of various authorities. It is provided that not only documentation and ballots should be in Ukrainian, but also election campaigning carried out at the expense of the state budget.

The Law provides for the formation of a special institution of Commissioner authorized to protect the state Ukrainian language. The Commissioner will be appointed by the government for a period of five years and will be assisted in the work by 27 language inspectors. Anyone can complain to the Commissioner if his/her right to receive information in the Ukrainian language is violated. Written complaints can be filed within two years of the discovery of the violation. The language inspectors will study such incidents on the ground, draw up a protocol and have the right to bring violators to administrative responsibility. For example, the officials face a fine of 200 to 400 tax-free minimum incomes (from 3400 to 6800 hryvnia)for the non-use of the Ukrainian language. Naturally, such a state-language dictatorship initially becomes a destabilizing factor, since it affects quite large social strata.

The Law also proposes to teach in Ukrainian in all educational institutions. At the same time, in educational institutions of national minorities, a language of national minority may be used along with the Ukrainian language, but the procedure for the use of a non-state language in educational institutions will be spelled out in the Law "On the Rights of Persons Belonging to National Minorities," the draft of which is also under development.It should be emphasized that this legal norm does not quite fit into the requirements of the European Charter "On regional languages or languages of national minorities," which Ukraine has ratified.

The Law provides that entertainment and cultural activities shall also be conducted in the state language. Ukrainian will also be the language of television and other media. Programs in other languages should be translated in the state Ukrainian language. If during the live broadcast one of the participants speaks another language, the Ukrainian translation of his words should be provided. Only songs are exempt from this provision. Owners of print media will be allowed to publish their periodicals in several language versions, one of which shall necessarily be Ukrainian and should constitute at least half of the total circulation. These rules will come into force one year after the adoption of the Law.

The most politically radical is the legal provision of the Law, according to which the attempt to introduce an official multilingualism is equivalent to an attempt to overthrow the state system of Ukraine and is punishable by up to 10 years ofimprisonment. The document also provides for the abolition of the Law "On the Basics of the 
State Language Policy," adopted in 2012.

O. Yurinets,one of the authors of the draft Law "On the State Language" argues that their initiative is important and necessary: "Those who listen to criticism should understand that in our realities there is no particularly convenient time for any bill. Even the most perfect law is always criticized. There is no need to look for something negative in this document. It is necessary to look at it and at the problem from the state position. In France, any official must know French, in Poland - Polish, and here in Kiev,at official events I am often offered a choice between English and Russian and I have to defend my right to the Ukrainian."

But this is not the only legislative initiative in the field of the language proposed by the deputies for the consideration of the Ukrainian Parliament at the end of its work. Three bills regulating the use of different languages and the use of Ukrainian as the state language in modern Ukraine were registered in the Rada. For example, the draft Law "On the Functioning of the Ukrainian Language as the State Language and the Procedure for the Use of Other Languages in Ukraine," registered by a group of seven deputies, differs from the above draft becauseit already contains a mechanism for the protection of the languages of national minorities.Its authors also proposed to introduce the institution of the Commissioner for the protection of the Ukrainian state language,but its sphere of responsibility would also concern the use of the languages of national minorities and protection of their rights in the language sphere. Another bill "On Languages in Ukraine," introduced at the end of 2016, in fact, only spelled out the procedure for the use of languages in the country .

A concept of any language reform should always havea prognostic part that is supposed to occupy an important place. In this regard, we present interesting considerations on the regulation of language policy and the development of languages with the account of the prevailing cultural and historical realities presented some time ago by the Research Center for national and linguistic relations of the Institute of Linguistics of the Russian Academy of Sciences for the republics of post-Soviet Russia. These recommendations, in our view, can be safely applied to all former USSR Republics. According to the Center, the following options for further development of national-language relations are possible.

The first approach is a balanced and realistic option. In the Republics where laws on languages have been adopted or are being discussed, Russian is recognized as the state language or the language of interethnic communication along with the recognition of the state language of indigenous nationality. Thus, the national-Russian bilingualism is legislated, helping to gradually increase the linguistic competence of the population in the sphere of the state language of the Republic, where gradually means in accordance with the expediency to expand its functions.Language proficiency requirements are implementedwithin a sufficient period of time by setting a social perspective to the learning youth, as well as by increasing the interest of the foreign-speaking population to the culture and language of the local population. In this case, a good material basis is created for the learningof the state language, creating favorable conditions for the development of conflict-free national-language relations.

The second option is an extremist version of "language expansion." It is associated with the development of nationalist, separatist sentiments ignoring the realities, and partly with the desire to use the language problem in political purposes. This option involves the establishment of strict deadlines for the introduction of the state language in different spheres of communication, ignoring the real social needs of the language community.It has insufficient consideration for the language claims of the non-indigenous residents, for the formulation of the language rights of the nation over the language rights of the individual.This option is fraught with national conflicts with all the negative social consequences: a clash of interests of different national groups, an increase in the level of migration, infringement of the linguistic rights of some residents, national minorities, etc.

Until the last presidential election and election of V. ZelenskyPresident of Ukraine, the Law "On the Basics of the State Language Policy" of June 3, 2012 allowed the use of two languages (Ukrainian and Russian) in 13 of the 27 regions of the country. Article 10 of the Constitution of Ukraine establishes that the state language in Ukraine is the Ukrainian language. At the same time, the Ukrainian state guaranteed the free development, use and protection of the Russian language and other languages of national minorities in Ukraine. At the moment, the legal basis of the state contributes to the study of languages of international communication and the use of languages in Ukraine is guaranteed by the Constitution of Ukraine and is determined by a special law.

In 2012, the Verkhovna Rada of Ukraine on the initiative of the deputies from the Party of Regions adopted the Law "On the Basics of the State Language Policy." The effect of the law was mandatory nationwide and was based on the results of the answersto the question about the native language, asked during the census in Ukraine, provided that more than $10 \%$ of the population named the language as its mother tongue.

But the political process in Ukraine over the past two decades has become abrupt. On February 23, 2014, 
immediately after the well-known events in Ukraine, the Verkhovna Rada voted for the abolition of the Law, arousing indignation of local authorities in the regions that had benefited from the opportunities provided by the canceled Law, that did not yet come into force.

On March 3, 2014,Oleksandr Turchynov, acting President of Ukraine, said that he would not sign the Parliament's decision to repeal the Law on language policy until the Verkhovna Rada adopted a new law. In this way, until the last presidential elections of 2019, this Law was not repealed and was in force.Such uncertainty has become another factor of radicalization of the state language policy in Ukraine.

Active struggle with all Russian and Soviet began in Ukraine in 2014, immediately after the events on the "Maidan." Even then, the deputies of the Verkhovna Rada demanded to ban the Russian language, as well as all Communist symbols, reminiscent of the Soviet past.

In recent years, in Ukraine "there are various processes associated with the regional differentiation of the country, as well as the policy of Ukrainization." This, in particular, is the reason for the most important role of the language policy (primarily in relation to the Russian language), a factor that can both ensure political stability in Ukraine and destabilize the ethno-linguistic situation.

At the same time, it is obvious that "the balance between representatives of different ethnic communities and protection of the rights of national minorities are indicators of a developed modern democratic society."

Russian politicians have already called the new law of Ukrainian deputies "linguistic genocide," and Viktor Medvedchuk, Kiev representative in the humanitarian subgroup on Donbass, said that the consideration of the bill on the exclusive use of the Ukrainian language in almost all spheres of life threatens to grow into an international scandal. "Their legal novelties, which contradict the Constitution of Ukraine and discriminate a significant part of the country's citizens for the implementation of the national ideas, have become not only an internal problem of Ukraine, but also an occasion for an international scandal," Medvedchuk noted. He quoted Hungarian foreign Minister Peter Szijjarto, who, commenting on the Ukrainian bills on language and education, said that the Hungarian authorities "will not tolerate any amendments to the laws on education and on the use of the languages that would worsen the situation of the minorities." Otherwise, this issue will be raised at the EU level.

At the same time, according to some experts, the Ukrainian government simply distracts the attention of the population from the socio-economic problems by introducing this bill. "The very appearance of the bill isa part of political technology: they introduce a topic of contention, which has been used more than once in the last ten years. If you start talking about the language, it is necessary to prepare for unpleasant events," said political analyst Viktor Nebozhenko. "Deputies won't pass the bill. It's simply a topic forarguments."

However, it should be remembered that Ukraine has ratified the European Charter "On Regional Languages and Languages of National Minorities." This Charter is essentially a European standard of cultural and language policy, one of the main principles of which is the preservation and development of the wealth and diversity of the cultural heritage of Europe, it develops the provisions on language rights contained in the European Convention for the protection of human rights and fundamental freedoms and the framework Convention for the protection of national minorities.

As it is demonstrated by the recent events in Ukraine related to the legislative restrictions at the schools for the languages of national minorities, suchEuropean countries as Bulgaria, Hungary and Poland,along with Russia,have sharply criticized the state language policy of Ukraine and demanded to bring it in line with the requirements of international law. Although we cannot expectradical changes in the language policy of Ukraine in the near future, but the official authorities will apparentlyhaveto adjust the situationin this area.

\section{Conclusions}

Thus, our analysis of the current situation around the Law on the language adopted in Ukraine shows not only the inconsistency and specificity of the language policy in the country, but also the additional tension in the relations between different groups of the population. Language neutrality in Ukraine today has not become the property of its domestic and foreign policy. The adopted Law became the basis for the development of the legislative process in the linguistic, cultural, social and political spheres on the basis of the promotion and development of the Ukrainian language as the state language. The Ukrainian language received an impulse for the development and self-development, for the functioning under the umbrella of the state and state power. It can be said that at the momentUkraine has developed a language legislation that puts the Ukrainian language in the status of the only languageand is directed at reducing the role and importance of other languages, especially Russian. Other languages and the Russian language in Ukraine are now developing outside the government 
and/or against it. Under such language policy in the country,the Ukrainian language is supposed to become the only language of education and mass culture (big press, radio, television and advertising) and as a result, even the language of everyday life, thus provoking separatism.

Phenomena similar to the Ukrainian events and processes now tend to grow in the area of the former Soviet Union. Ethno-linguistic policy for the new post-Soviet states is becoming one of the most difficult in making political decisions on the status of the state language, as the age-old culture and intercultural relations with the Russian language and culture are deeply rooted in the minds of the peoples of the former USSR. Therefore, any decisions of the authorities become a source of ethno-political destabilization, and, as evidenced by the events in Abkhazia, Moldova, Karabakh and Ukraine, even ethno-separatism..

\section{References}

Ahmadi, A. K., Zamani, M., \& Sarzaym, M. (2014). A survey of the spiritual intelligence in organizations with an emphasis on Islamic texts. UCT Journal of Social Sciences and Humanities Research, 2(2), 29-36.

Ketsyan, G. V. (2011). Ethno-linguistic policy as an institutional factor in the development of interethnic relations in the post-Soviet space (on the examples of Russia, Armenia and Ukraine). Thesis for the degree of Candidate of political sciences: 23.00.04. M.

Medvedev, N. P., Nesterchuk, O. A., \& Slizovsky, D. E. (2018). Post-Soviet commonwealth (CIS). Are there any resources left for a new reintegration? Przeglad Strategiczny, 11.

Mikhalchenko, V. Yu. (n.d.). Language conflict in a multi-ethnic state. Retrieved from http://philology.ru/linguistics1/mikhalchenko-14a.htm

Platonov, V. M., Zhiltsov, S. S., \& Glebov, V. A. (2015). Constitutional reform in Ukraine: basic stages of development. Issues of national and federative relations, 4(31).

Pyzh, V. V., \& Frolov, A. E. (2018). Political Security of the State and Political Stability of the Society as an Object of Political Analysis. Political Science Issues, 8(1).

Roland, B. (n.d.). The Rustle of Languages. Retrieved July 17, 2019, from https://gigabaza.ru/doc/172365.html

Savitskiy, A. (n.d.). Russian language in Ukraine: what changes after the Law on the state language comes into force. Retrieved July 17, 2019, from https://news.tut.by/world/645736.html

Slisovskiy, D. E., \& Medvedev N. P. (2018). International Security Challenges in the Perception of Russian Students. Bulletin of the Peoples' Friendship University of Russia. Series: Sociology, 18(3). https://doi.org/10.22363/2313-2272-2018-18-3-443-451

\section{Copyrights}

Copyright for this article is retained by the author(s), with first publication rights granted to the journal.

This is an open-access article distributed under the terms and conditions of the Creative Commons Attribution license (http://creativecommons.org/licenses/by/4.0/). 